\title{
Pertumbuhan dan produksi rumput gajah odot dan kacang tanah pada sistem pertanian campuran dengan berbagai jarak dan waktu tanam
}

\author{
Growth and production of elephant grass cv. Odot and peanut under mixed cropping system \\ with various distances and planting time
}

\author{
Alama Dian Rahayu ${ }^{1 *}$, Didik Wisnu Widjajanto ${ }^{1}$, dan Sutarno ${ }^{1}$ \\ ${ }^{1}$ Departemen Pertanian, Fakultas Peternakan dan Pertanian, Universitas Diponegoro, Semarang, Jawa Tengah, Indonesia \\ *Email korespondensi: alamadian007@gmail.com
}

Diterima: 28 Juli 2021 / Disetujui: 19 Agustus 2021

\begin{abstract}
The purpose of the research was to examine the effect of the spacing of Elephant grass cv Odot and planting times of peanuts on the growth and production of Elephant grass cv Odot and peanuts. Field experiment was carried out in Kalongan village, East Ungaran subdistrict, Semarang District, Central Java Province. Analysis of soil and plant characteristics was conducetd at the ecology and plant production laboratory, Diponegoro University, from September 2020 to February 2021 . A factorial trial based a randomized block design with 2 factors and 3 replication was used througout the experiment. The first factor was the spacing of Elephant grass cv Odot which consisted of J1:90 cm x $60 \mathrm{~cm}$, and J2: $90 \mathrm{~cm} \times 45 \mathrm{~cm}$. The second factor was the peanuts planting time which consisted of $T 1: 2$-week prior to defoliation, T2:1-week prior to defoliation, T3 : at the time of defoliation, T4 : 1-week after defoliation. The data obtained were analyzed statistically using analysis of variance and further tested using Duncan's test at a 5\% confidence level. The results showed that the treatment of Elephant grass cv Odot spacing showed significant effect on the number of peanut pods, while the treatment of peanuts planting time showed a significant effect on the number of tillers and fresh weight of Elephant grass cv Odot, height and number of leaves peanuts, and weight of 100 peanuts. Based on the results of the experiment, it may be concluded that the cultivation of peanuts may be recommended to mix planting with Elephan grass cv Odot.
\end{abstract}

Keywords: elephant grass cv odot, growth, mixed cropping, peanuts, production.

\section{ABSTRAK}

Penelitian bertujuan mengkaji perlakuan jarak tanam rumput gajah var. odot dan waktu tanam kacang tanah terhadap pertumbuhan serta produksi rumput gajah var. odot dan kacang tanah. Penelitian lapang dilaksanakan di Desa Kalongan, Kecamatan Ungaran Timur, Kabupaten Semarang. Analisis karakteristik tanah dan tanaman dilakukan di Laboratorium Ekologi dan Produksi Tanaman, Fakultas Peternakan dan Pertanian, Universitas Diponegoro, Semarang dari bulan September 2020 sampai Februari 2021. Percobaan faktorial $2 \times 4$ dengan rancangan acak kelompok dengan 3 kelompok ulangan. Faktor pertama jarak tanam rumput gajah var. odot terdiri dari $J 1: 90 \mathrm{~cm} \times 60 \mathrm{~cm}$, dan J2:90 cm x $45 \mathrm{~cm}$. Faktor kedua waktu tanam kacang tanah terdiri dari T1 : 2 minggu sebelum potong paksa, T2 : 1 minggu sebelum potong paksa, T3 : pada saat potong paksa, dan T4 : 1 minggu setelah potong paksa. Data yang diperoleh dianalisis secara statistik menggunakan analisis varians dan selanjutnya diuji menggunakan uji Duncan pada taraf kepercayaan 5\%. Hasil penelitian menunjukkan bahwa pada perlakuan jarak tanam rumput gajah var. odot berpengaruh nyata pada jumlah polong kacang tanah, sedangkan perlakuan waktu tanam kacang tanah menunjukkan pengaruh nyata terhadap jumlah anakan dan berat basah rumput odot, tinggi, jumlah daun, dan berat 100 biji kacang tanah. Berdasarkan hasil percobaan dapat disimpulkan bahwa budidaya kacang tanah dapat direkomendasikan untuk ditanam campur dengan rumput gajah var. odot.

Kata kunci: kacang tanah, pertumbuhan, produksi, rumput gajah var. odot, sistem pertanaman campuran.

\section{PENDAHULUAN}

Meningkatnya jumlah penduduk menyebabkan kebutuhan hasil pertanian semakin meningkat (Manyamsari dan Mujiburrahmat, 2014), baik kebutuhan pangan nabati maupun hewani. Pemenuhan pangan hewani tidak lepas dari kegiatan bercocok tanam, yaitu berupa penyediaan hijauan pakan untuk memenuhi kebutuhan gizi ternak, sehingga ternak dapat tumbuh dengan baik dan menghasilkan produk pangan hewani berkualitas baik. Kualitas hijauan pakan terbukti berpengaruh terhadap pertumbuhan dan perkembangan, serta produktivitas hewan ternak (Saputro et al., 2018).

Rumput gajah var. Odot (Pennisetum purpureum cv. Mott) atau disebut juga sebagai rumput gajah mini atau rumput gajah kate merupakan salah satu hijauan pakan 
berpotensi produksi tinggi. Rumput gajah var. Odot termasuk rumput unggul dengan tingkat kecernaan tinggi dan cukup mudah untuk dibudidayakan. Rumput gajah var. Odot mempunyai karakter perakaran kuat, batang tidak keras, menghasilkan banyak anakan, ruas daun pendek dan banyak serta struktur daun tidak keras dan berbulu halus sehingga disukai oleh ternak (Lasamadi et al., 2013). Rumput gajah var. Odot merupakan salah satu hijauan pakan dengan kecernaan tinggi sebab kandungan karbohidrat struktural rendah dan mengandung $13,55 \% \mathrm{BK}, 10-15 \% \mathrm{PK}, 56,74 \%$ NDF, 38,23\% ADF, 85,55\% BO, dan $3.957 \mathrm{kkal} / \mathrm{g}$ energi (Sirait, 2017).

Tanaman kacang tanah (Arachis hypogea L.) merupakan salah satu kacang-kacangan yang mengandung protein tinggi dan salah satu sumber minyak nabati. Tanaman kacang tanah merupakan salah satu tanaman yang dapat bersimbiosis dengan bakteri perakaran berupa rhizobium. Rhizobium merupakan bakteri perakaran yang dapat menambat nitrogen bebas di udara dan mengubahnya menjadi ammonia dan nitrat yang selanjutnya dimanfaatkan langsung oleh tanaman (Sari dan Prayudyaningsih, 2017). Kacang tanah unggulan dengan produksi tinggi dan tahan penyakit salah satunya adalah kacang tanah varietas Katana-1. Kacang tanah varietas Katana-1 merupakan varietas unggul tahan penyakit bercak daun pada taraf moderat dan tahan terhadap penyakit layu, serta mempunyai potensi hasil tinggi sampai dengan $4,8 \mathrm{t} / \mathrm{ha}$, mengandung $28,9 \%$ protein, dan $46,9 \%$ lemak (Balitkabi, 2018).

Rumput gajah var. Odot biasa ditanam dengan jarak lebar, sehingga menyisakan ruang di antara jarak tanamnya. Ruang kosong tersebut dapat dimanfaatkan untuk menanam tanaman lain dengan cara tumpangsari. Tanaman yang cocok digunakan dalam budidaya secara tumpangsari yaitu tanaman legum salah satunya yaitu tanaman kacang tanah. Sistem tanam tumpangsari memiliki kelebihan diantaranya yaitu efisiensi penggunaan lahan, serta menghemat penggunaan pupuk nitrogen dengan menanam tanaman legum. Sistem tanam tumpangsari dapat meningkatkan efektivitas dan efisiensi secara ekologi dan agronomi karena dapat menghasilkan lebih dari satu produk tanaman di tempat yang sama dalam satu waktu (Lestari et al., 2019).

Kelemahan sistem tumpangsari yaitu timbulnya persaingan antar tanaman yang dibudidayakan (Kesuma et al., 2018). Untuk memperkecil adanya persaingan antar tanaman maka diperlukan pengaturan jarak tanam serta waktu tanam sehingga persaingan yang terjadi dapat diperkecil. Penelitian bertujuan untuk mengkaji pengaruh perlakuan jarak tanam rumput gajah var. odot dan waktu tanam kacang tanah terhadap pertumbuhan serta produksi rumput gajah var. odot dan kacang tanah.

\section{BAHAN DAN METODE}

Penelitian lapang dilaksanakan pada tanggal 15 September 2020 sampai 9 Februari 2021 di Desa Kalongan, Kecamatan Ungaran Timur, Kabupaten Semarang.Kecamatan Ungaran Timur berada pada titik koordinat $7^{\circ} 08^{\prime} 27^{\prime \prime}$ - 7 $7^{\circ} 15^{\prime} 72^{\prime \prime}$ LS, dan 110 $40^{\prime} 88^{\prime \prime}$ $110^{\circ} .48^{\prime} 14$ " BT . Topografi berupa daratan dan lereng dengan ketinggian tempat antara 80 sampai $399 \mathrm{~m} \mathrm{dpl} \mathrm{(BPS,} \mathrm{2019),}$ suhu harian rata-rata $28,4{ }^{\circ} \mathrm{C}$, kelembaban udara $76,4 \%$ (BMKG, 2019) dan dengan curah hujan $2.314 \mathrm{~mm} /$ tahun (BPS, 2017). Kecamatan ungaran timur terdiri dari 10 desa yaitu Beji, Leyangan, Kalongan, Kawengen, Kalikayen, Mluweh, Susukan, Kalirejo, Sidomulyo, dan Gedanganak. Kecamatan ungaran timur berbatasan langsung dengan Kecamatan Ungaran Barat di sebelah barat, Kabupaten Demak di sebelah timur, Kota Semarang di sebelah utara serta Kecamatan Bergas dan Kecamatan Pringapus di sebelah selatan (BPS, 2017).

Alat yang digunakan pada penelitian yaitu meteran, cangkul, pisau, mistar, timbangan, sabit, kamera, hygrometer, dan selang. Bahan yang digunakan dalam penelitian yaitu stek batang rumput gajah var. odot, benih kacang tanah varietas Katana-1, pupuk kompos, kabel ties, paralon, plastik klip, dan tali rafia.

Penelitian dilakukan dalam beberapa tahap yaitu analisis tanah dan pupuk kompos, persiapan lahan, penanaman, potong paksa rumput gajah var. odot, pemeliharaan, dan panen. Persiapan lahan dilakukan dengan menyiapkan petak berukuran $2 \mathrm{~m} \mathrm{x} 3 \mathrm{~m}$, diolah dan ditambah pupuk kompos $6 \mathrm{~kg} /$ petak. Penanaman rumput gajah var. odot dilakukan 1 minggu setelah persiapan lahan, dengan jarak tanah disesuaikan perlakuan yaitu $90 \mathrm{~cm}$ x $60 \mathrm{~cm}$, dan $90 \mathrm{~cm}$ x $45 \mathrm{~cm}$. Waktu penanaman kacang tanah dilakukan sesuai dengan perlakuan yaitu 2 minggu sebelum potong paksa, 1 minggu sebelum potong paksa, pada saat potong paksa dan 1 minggu setelah potong paksa dengan jarak tanam $40 \mathrm{~cm}$ x 15 $\mathrm{cm}$. Potong paksa rumput gajah var. odot dilakukan pada umur rumput 40 hari setelah tanam (HST). Pemeliharaan meliputi penyiraman, penyiangan, pendangiran dan pembumbunan. Pemanenan atau defoliasi rumput gajah var. odot dilakukan pada 40 HST. Pemanenan kacang tanah dilakukan pada 98 HST.

Penelitian dilakukan menggunakan rancangan faktorial 2 x 4 dengan rancangan acak kelompok dengan 3 kelompok ulangan. Faktor pertama jarak tanam rumput gajah var. odot terdiri dari J1: $90 \mathrm{~cm} \mathrm{x} 60 \mathrm{~cm}$, dan J2: $90 \mathrm{~cm}$ x 45 $\mathrm{cm}$. Faktor kedua waktu tanam kacang tanah terdiri dari T1 : 2 minggu sebelum potong paksa, T2 : 1 minggu sebelum potong paksa, T3 : pada saat potong paksa, dan T4 : 1 minggu setelah potong paksa. Data yang diperoleh kemudian dianalisis secara statistik menggunakan sidik ragam dan pada perlakukan yang menunjukkan beda nyata diuji lanjut dengan Uji Jarak Berganda Duncan (UJGD) taraf 5\%.

\section{HASIL DAN PEMBAHASAN}

Berdasarkan analisis ragam jumlah anakan rumput gajah var. odot tidak menunjukkan pengaruh nyata terhadap jumlah anakan, sedangkan waktu tanam kacang tanah menunjukkan pengaruh nyata terhadap jumlah anakan. Hasil uji Duncan jumlah anakan rumput gajah var. odot pada fase pertumbuhan setelah potong paksa disajikan pada Tabel 1, dan setelah defoliasi 1 disajikan pada Tabel 2.

Berdasarkan Tabel 1 dapat diketahui bahwa perlakuan waktu tanam kacang tanah memberikan pengaruh terhadap jumlah anakan tertinggi adalah T4 (1 minggu setelah potong 
paksa). Perlakuan T4 (1 minggu setelah potong paksa) menghasilkan jumlah anakan rumput gajah var. odot terbanyak dan diikuti oleh perlakuan T2 (1 minggu sebelum potong paksa), lalu perlakuan T1 (2 minggu sebelum potong paksa) dan yang paling rendah pada perlakuan T3 (pada saat potong paksa).

Berdasarkan Tabel 2 di atas dapat diketahui bahwa perlakuan waktu tanam kacang tanah memberikan pengaruh nyata terhadap jumlah anakan rumput odot pada 1 minggu setelah defoliasi 1 dan 4 minggu setelah defoliasi 1. Jumlah anakan rumput odot rerata terbanyak diperoleh dari perlakuan T4 (1 minggu setelah potong paksa). Penanaman kacang tanah perlakuan T4 (1 minggu setelah potong paksa) yang dilakukan 1 minggu setelah potong paksa yaitu 47 hari setelah penanaman rumput gajah var. odot dimungkinkan perakaran rumput gajah var. odot yang telah menyebar dibawah permukaan tanah, sehingga penyerapan unsur hara rumput gajah var. odot lebih dominan dari kacang tanah, dan pertumbuhan tanaman termasuk pertumbuhan tunas lebih baik. Hal ini menyebabkan pertumbuhan tunas rumput gajah var. odot menjadi lebih baik. Luthfiana et al. (2019) menyatakan bahwa dalam persaingan pengambilan unsur hara tanaman yang tidak mampu bersaing dalam mendapatkan unsur hara yang diperlukan maka pertumbuhannya akan terganggu. Didukung Amin dan Zubaidah (2018) bahwa tingkat kepadatan rendah menyebabkan ruang tumbuh luas sehingga memberikan ruang lebih baik untuk penyerapan unsur hara dan merangsang pertumbuhan tunas tanaman rumput gajah var. Odot.

Tabel 1. Rerata jumlah anakan rumput odot pada perlakuan jarak tanam rumput odot dan waktu tanam kacang tanah setelah potong paksa

\begin{tabular}{|c|c|c|c|c|c|c|}
\hline \multicolumn{2}{|c|}{ Perlakuan } & \multicolumn{5}{|c|}{$\begin{array}{l}\text { Jumlah Anakan Rumput Odot } \\
\text { (Minggu setelah Potong Paksa) }\end{array}$} \\
\hline & & 1 & 2 & 3 & 4 & 5 \\
\hline & & & . & -batan & -------. & \\
\hline \multirow{2}{*}{ Jarak Tanam Odot } & $\mathrm{J} 1$ & 2.75 & 3.22 & 4.84 & 4.48 & 5.71 \\
\hline & $\mathrm{J} 2$ & 2.22 & 2.57 & 3.89 & 3.84 & 4.34 \\
\hline \multicolumn{2}{|c|}{ Rata-rata } & 2.49 & 2.90 & 4.37 & 4.16 & 5.03 \\
\hline \multirow{4}{*}{$\begin{array}{l}\text { Waktu Tanam } \\
\text { Kacang Tanah }\end{array}$} & $\mathrm{T} 1$ & $2.55^{\mathrm{ab}}$ & $2.53^{b}$ & 3.53 & $3.23^{\mathrm{b}}$ & $3.59^{b}$ \\
\hline & $\mathrm{T} 2$ & $2.41^{\mathrm{ab}}$ & $2.86^{\mathrm{b}}$ & 4.04 & $4.10^{\mathrm{ab}}$ & $4.84^{b}$ \\
\hline & $\mathrm{T} 3$ & $1.70^{\mathrm{b}}$ & $1.95^{\mathrm{c}}$ & 3.06 & $3.15^{\mathrm{b}}$ & $3.39^{b}$ \\
\hline & T4 & $3.27^{\mathrm{a}}$ & $4.25^{\mathrm{a}}$ & 6.83 & $6.89^{a}$ & $8.26^{a}$ \\
\hline \multicolumn{2}{|c|}{ Rata-rata } & 2.48 & 2.90 & 4.36 & 4.42 & 5.02 \\
\hline
\end{tabular}

Keterangan: Angka yang diikuti oleh huruf yang sama pada kolom yang sama menunjukkan berbeda tidak nyata menurut uji Duncan pada taraf 5\%

Tabel 2. Rerata jumlah anakan rumput odot pada perlakuan jarak tanam rumput odot dan waktu tanam kacang tanah setelah defoliasi 1

\begin{tabular}{|c|c|c|c|c|c|c|}
\hline \multirow{2}{*}{\multicolumn{2}{|c|}{ Perlakuan }} & \multicolumn{5}{|c|}{$\begin{array}{l}\text { Jumlah Anakan Rumput Odot } \\
\text { (Minggu setelah Defoliasi 1) }\end{array}$} \\
\hline & & 1 & 2 & 3 & 4 & 5 \\
\hline & & \multicolumn{5}{|c|}{---------------------------------batang---------------------------- } \\
\hline Jarak Tanam & $\mathrm{J} 1$ & 8.54 & 9.17 & 8.48 & 7.9 & 9.4 \\
\hline Odot & $\mathrm{J} 2$ & 7.33 & 8.04 & 8.65 & 8.26 & 8.54 \\
\hline \multicolumn{2}{|c|}{ Rata-rata } & 7.94 & 8.61 & 8.57 & 8.08 & 8.97 \\
\hline \multirow{4}{*}{$\begin{array}{l}\text { Waktu Tanam } \\
\text { Kacang Tanah }\end{array}$} & $\mathrm{T} 1$ & $5.24^{\mathrm{b}}$ & 6.37 & 6.41 & $5.55^{b}$ & 6.64 \\
\hline & $\mathrm{T} 2$ & $7.09^{b}$ & 7.95 & 7.86 & $7.31^{\mathrm{b}}$ & 9.17 \\
\hline & T3 & $5.49^{b}$ & 6.64 & 7.42 & $6.97^{\mathrm{b}}$ & 6.9 \\
\hline & $\mathrm{T} 4$ & $13.93^{a}$ & 13.48 & 12.57 & $12.48^{\mathrm{a}}$ & 13.16 \\
\hline \multicolumn{2}{|c|}{ Rata-rata } & 7.94 & 8.61 & 8.57 & 8.08 & 8.97 \\
\hline
\end{tabular}

Keterangan: Angka yang diikuti oleh huruf yang sama pada kolom yang sama menunjukkan berbeda tidak nyata menurut uji Duncan pada taraf $5 \%$ 


\section{Berat Basah Rumput Odot}

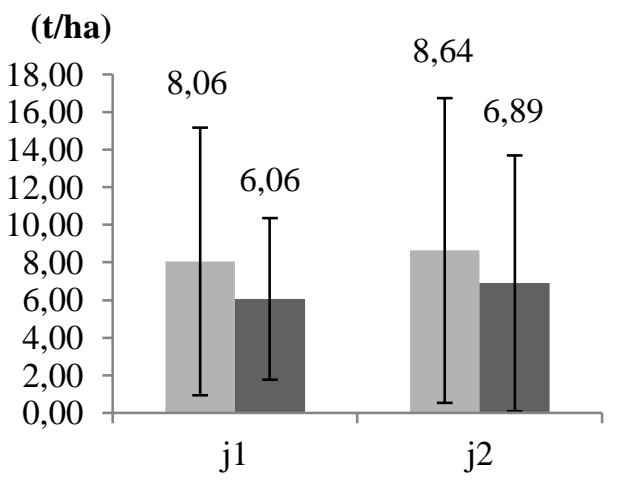

Jarak Tanam Rumput Odot

Defoliasi 1 Defoliasi 2

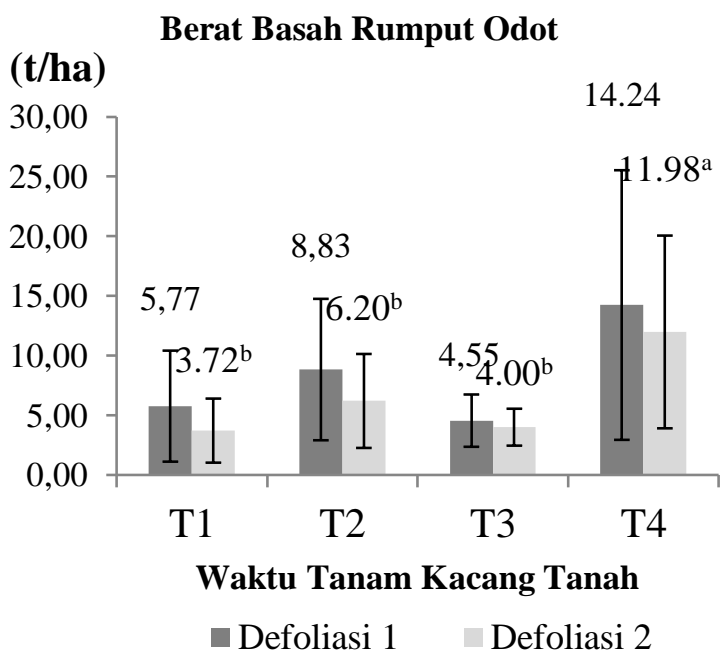

Gambar 1. Diagram pengaruh jarak tanam rumput odot dan waktu tanam kacang tanah terhadap berat basah rumput odot

Tabel 3. Rerata tinggi tanaman kacang tanah pada perlakuan jarak tanam rumput odot dan waktu tanam kacang tanah

\begin{tabular}{|c|c|c|c|c|c|c|c|c|}
\hline Perlakuan & $1 \mathrm{MST}$ & $2 \mathrm{MST}$ & $3 \mathrm{MST}$ & $4 \mathrm{MST}$ & $5 \mathrm{MST}$ & $6 \mathrm{MST}$ & $7 \mathrm{MST}$ & $8 \mathrm{MST}$ \\
\hline $\mathrm{J} 1$ & 1.71 & 5.96 & 10.53 & 14.32 & 19.15 & 25.06 & 34.3 & 40.07 \\
\hline $\mathrm{J} 2$ & 1.67 & 6.22 & 11.78 & 15.45 & 20.58 & 26.83 & 34.57 & 40.81 \\
\hline Rata-rata & 1.69 & 6.09 & 11.16 & 14.89 & 19.87 & 25.95 & 34.44 & 40.44 \\
\hline $\mathrm{T} 1$ & $1.87^{\mathrm{a}}$ & 6.59 & $10.89^{b}$ & $14.26^{b}$ & $16.1^{\mathrm{c}}$ & $20.11^{c}$ & 31.89 & 38.24 \\
\hline $\mathrm{T} 2$ & $2.08^{a}$ & 5.82 & $10.26^{b}$ & $12.29^{b}$ & $15.54^{\mathrm{c}}$ & $24.07^{b c}$ & 33.02 & 39.26 \\
\hline $\mathrm{T} 3$ & $1.98^{\mathrm{a}}$ & 6.08 & $9.37^{b}$ & $12.64^{b}$ & $21.33^{b}$ & $27.14^{b}$ & 33.49 & 40.68 \\
\hline $\mathrm{T} 4$ & $0.82^{b}$ & 5.88 & $14.11^{\mathrm{a}}$ & $20.36^{\mathrm{a}}$ & $26.47^{\mathrm{a}}$ & $32.46^{\mathrm{a}}$ & 39.35 & 43.59 \\
\hline Rata-rata & 1.69 & 6.09 & 11.16 & 14.89 & 19.86 & 25.95 & 34.44 & 40.44 \\
\hline
\end{tabular}

Keterangan: Angka yang diikuti oleh huruf yang sama pada kolom yang sama menunjukkan berbeda tidak nyata menurut uji Duncan pada taraf $5 \%$

Tabel 4. Rerata jumlah daun kacang tanah pada perlakuan jarak tanam rumput odot dan waktu tanam kacang tanah

\begin{tabular}{ccccccccc}
\hline Perlakuan & 1 MST & 2 MST & 3 MST & 4 MST & 5 MST & 6 MST & 7 MST & 8 MST \\
\hline J1 & 2.12 & 7.21 & 10.85 & 14.1 & 19.49 & 27.24 & 32.79 & 37.73 \\
J2 & 2.17 & 6.92 & 10.68 & 14.72 & 18.85 & 26.25 & 32.42 & 38.42 \\
\hline Rata-rata & 2.15 & 7.07 & 10.77 & 14.41 & 19.17 & 26.75 & 32.61 & 38.08 \\
\hline T1 & $2.01^{\mathrm{b}}$ & $7.97^{\mathrm{a}}$ & 11.04 & 15.02 & 17.98 & 26.92 & 33.34 & 37.22 \\
T2 & $1.98^{\mathrm{b}}$ & $6.24^{\mathrm{c}}$ & 9.88 & 13.1 & 20.54 & 27.84 & 32.66 & 38.59 \\
T3 & $2.67^{\mathrm{a}}$ & $7.35^{\mathrm{ab}}$ & 10.94 & 15.14 & 20.2 & 29.31 & 35.53 & 41.42 \\
T4 & $1.93^{\mathrm{b}}$ & $6.7^{\mathrm{bc}}$ & 11.21 & 14.38 & 17.96 & 22.92 & 28.9 & 35.09 \\
\hline Rata-rata & 2.15 & 7.07 & 10.77 & 14.41 & 19.17 & 26.75 & 32.61 & 38.08
\end{tabular}

Keterangan: Angka yang diikuti oleh huruf yang sama pada kolom yang sama menunjukkan berbeda tidak nyata menurut uji Duncan pada taraf $5 \%$

Perlakuan waktu tanam kacang tanah tidak berpengaruh nyata terhadap parameter bobot basah rumput gajah var. odot per petak perlakuan pada defoliasi pertama dan berpengaruh nyata pada defoliasi kedua. Berat basah tertinggi didapat dari perlakuan T4 yaitu 14,24 t/ha. Perlakuan T1 (2 minggu sebelum potong paksa), T2 (1 minggu sebelum potong paksa), dan T3 (pada saat potong paksa) tidak menunjukkan perbedaan hasil yang nyata dan berbeda nyata dengan perlakuan T4 (1 minggu setelah potong paksa). Berat basah rumput gajah var. odot disajikan pada diagram.

Berat basah rumput gajah var. odot defoliasi pertama dipengaruhi oleh pertumbuhan rumput gajah var. odot setelah potong paksa, yang tidak menunjukkan hasil berbeda nyata terhadap perlakuan jarak tanam, waktu tanam kacang tanah, 
maupun interaksi antara kedua perlakuan (Gambar 1). Hal ini diduga kebutuhan unsur hara yang diperlukan oleh tanaman masih terpenuhi dengan baik dari tanah maupun tambahan dari pupuk kandang yang diaplikasikan pada saat olah tanah, dan faktor pertumbuhan lainnya juga terpenuhi. Sesuai pendapat Amin et al. (2018) bahwa produksi rumput gajah var. odot dipengaruhi oleh ketersediaan unsur hara, iklim, dan sumber air.

Defoliasi kedua menunjukkan hasil berat basah rumput gajah var. odot berbeda nyata pada perlakuan waktu tanam kacang tanah, sedangkan untuk perlakuan jarak tanam rumput gajah var. odot, maupun kombinasi perlakuan tidak berbeda nyata. Unsur hara yang ada di dalam tanah berkurang karena diserap oleh tanaman selama pertumbuhan pada fase tanam hingga defoliasi pertama, sehingga unsur hara di dalam tanah terbatas. Peran tanaman kacang tanah menyediakan unsur hara nitrogen yang diperlukan oleh tanaman untuk proses pertumbuhan. Perlakuan T4 (1 minggu setelah potong paksa) mampu menunjukkan pengaruh terbaik dikarenakan ketika fase pertumbuhan setelah defoliasi pertama tanaman kacang tanah memasuki umur 4 minggu setelah tanam (MST) dimana rhizobium yang bersimbiosis dengan kacang tanah sedang aktif dalam menambat nitrogen. Suryantini (2015) menyatakan bahwa aktivitas penambatan nitrogen pada kacang tanah dimulai pada umur 25-30 hari dan kandungan leg-hemoglobin maksimum ketika pengisian polong kacang tanah.

Hasil analisis ragam menunjukkan bahwa perlakuan jarak tanam rumput odot tidak berpengaruh nyata terhadap tinggi tanaman kacang tanah dari minggu pertama hingga minggu ke-8. Perlakuan waktu tanam kacang tanah berpengaruh nyata terhadap parameter tinggi tanaman kacang tanah. Hasil uji Duncan tinggi tanaman kacang tanah disajikan pada Tabel 3.

Berdasarkan Tabel 3 diketahui bahwa tinggi tanaman kacang tanah tertinggi dicapai perlakuan T4 (1 minggu setelah potong paksa), diikuti perlakuan T3 (pada saat potong paksa), T2 (1 minggu sebelum potong paksa), dan paling rendah adalah perlakuan T1 (2 minggu sebelum potong paksa). Perlakuan T4 (1 minggu setelah potong paksa) penanaman kacang tanah dilakukan 1 minggu setelah potong paksa sehingga ketika tanaman kacang tanah mulai berkecambah dan tumbuh mengalami kondisi ternaungi oleh rumput odot yang telah tumbuh. Kondisi naungan menyebabkan penerimaan cahaya tanaman kacang tanah rendah.

Hasil tinggi tanaman kacang tanah akhir terendah diperoleh dari perlakuan T1 (2 minggu sebelum potong paksa). Hal ini dapat dikarenakan waktu penanaman dilakukan ketika rumput odot masih belum tumbuh secara optimal dan jumlah anakan yang masih sedikit, sehingga persaingan dalam mendapatkan cahaya matahari lebih rendah dari perlakuan waktu tanam yang lainnya. Menurut Permanasari dan Kastono (2012) tanaman yang ternaungi dalam waktu lama dapat mengalami etiolasi akibat peningkatan aktivitas auksin. Didukung oleh pendapat Dharmawangsa et al. (2020) yang menyatakan bahwa fotosintat tanaman akan dimanfaatkan untuk pertumbuhan tinggi secara optimum sebagai respon persaingan dalam memperoleh cahaya matahari. Berdasarkan hasil analisis ragam menunjukkan bahwa perlakuan jarak tanam tidak menunjukkan perbedaan nyata terhadap jumlah daun tanaman kacang tanah, sedangkan perlakuan waktu tanam kacang tanah berpengaruh nyata terhadap jumlah daun tanaman kacang tanah pada 1 MST dan 2 MST. Hasil uji Duncan jumlah daun kacang tanah disajikan pada Tabel 4.

Perbedaan jumlah daun nyata terjadi pada 2 minggu awal penanaman. Hal tersebut dapat dikarenakan ketika proses pembentukan awal daun pada 2 minggu pertama tanaman memanfaatkan unsur hara yang ada di dalam tanah, karena belum adanya simbiosis dengan rhizobium, sehingga proses pembentukan daun ditentukan oleh kandungan unsur hara yang ada di dalam tanah. Pertumbuhan tanaman termasuk jumlah daun sangat dipengaruhi oleh unsur hara terutama nitrogen. Menurut Sirenden et al. (2016) nitrogen berperan dalam pertumbuhan sebagai penyusun protoplasma, dimana tanaman yang tumbuh menambah jumlah dan ukuran sel. Waktu tanam berpengaruh pada awal penanaman juga dapat dikarenakan oleh adanya naungan dari rumput odot sehingga fotosintesis tanaman kacang tanah tidak optimal. Pembentukan daun pada kacang tanah dimulai pada 1 MST yaitu setelah tanaman kacang tanah berkecambah dan muncul ke permukaan tanah. pembentukan daun pada tanaman memerlukan unsur hara yang mencukupi dan sinar matahari yang cukup untuk melakukan proses fotosintesis. Perlakuan T3 (pada saat potong paksa) ditanam ketika rumput odot didefoliasi sehingga ketika tanaman kacang tanah mulai membentuk daun pencahayaan matahari yang diterima cukup sehingga proses fotosintesis optimal. Hasil fotosintat kemudian digunakan oleh tanaman dalam membentuk daun. Minggu ketiga hingga kedelapan pengamatan jumlah daun kacang tanah tidak menunjukkan hasil berbeda nyata. Hal ini terjadi karena pada minggu ke-3 tanaman sudah bersimbiosis dengan rhizobium, sehingga kebutuhan nitrogen yang diperlukan untuk pertumbuhan tercukupi. Didukung oleh pendapat Sadmaka et al. (2018) bahwa rhizobium yang bersimbiosis dengan akar kacang tanah dan membentuk bintil mampu mengikat unsur nitrogen dan dapat memenuhi kebutuhan nitrogen sebesar 80-90\% untuk pertumbuhan.

Berdasarkan hasil analisis ragam menunjukkan bahwa perlakuan jarak tanam rumput odot tidak menunjukkan perbedaan nyata terhadap bobot 100 biji kacang tanah, sedangkan perlakuan waktu tanam kacang tanah menunjukkan perbedaan nyata terhadap berat 100 biji kacang tanah. Hasil uji Duncan jumlah polong berisi kacang tanah disajikan pada Tabel 5.

Berdasarkan Tabel 5 diketahui bahwa perlakuan jarak tanam rumput odot tidak menunjukkan perbedaan nyata terhadap hasil berat 100 biji kacang tanah. Perlakuan waktu tanam kacang tanah menunjukkan perbedaan nyata terhadap berat 100 biji kacang tanah. Perlakuan waktu tanam T1 (2 minggu sebelum potong paksa), T2 (1 minggu sebelum potong paksa), dan T3 (pada saat potong paksa) tidak berbeda nyata, dan berbeda nyata dengan perlakuan waktu tanam kacang tanah, T4 (1 minggu setelah potong paksa). Hal ini dikarenakan tingkat kompetisi tanaman kacang tanah perlakuan T4 (1 minggu setelah potong paksa) lebih tinggi dibanding perlakuan lain. 
Tabel 5. Rerata berat 100 biji kacang tanah pada perlakuan jarak tanam rumput odot dan waktu tanam kacang tanah

\begin{tabular}{|c|c|c|c|c|c|}
\hline \multirow{2}{*}{ Perlakuan } & \multicolumn{3}{|c|}{ Ulangan } & \multirow{2}{*}{ Jumlah } & \multirow{2}{*}{ Rata-rata } \\
\hline & 1 & 2 & 3 & & \\
\hline \multicolumn{6}{|c|}{ _-- Jarak Tanam Rumput Odot -... } \\
\hline $\mathrm{J} 1$ & 41.70 & 45.79 & 43.77 & 131.26 & 43.75 \\
\hline $\mathrm{J} 2$ & 42.60 & 42.87 & 45.09 & 130.56 & 43.52 \\
\hline \multicolumn{6}{|c|}{ _. Waktu Tanam Kacang Tanah _-_ } \\
\hline $\mathrm{T} 1$ & 48.97 & 49.71 & 49.98 & 148.66 & $49.55^{\mathrm{a}}$ \\
\hline $\mathrm{T} 2$ & 48.13 & 42.24 & 48.73 & 139.10 & $46.37^{\mathrm{a}}$ \\
\hline $\mathrm{T} 3$ & 42.65 & 48.30 & 47.06 & 138.02 & $46.01^{\mathrm{a}}$ \\
\hline $\mathrm{T} 4$ & 28.85 & 37.06 & 31.95 & 97.87 & $32.62^{b}$ \\
\hline
\end{tabular}

Keterangan: Angka yang diikuti oleh huruf yang sama pada kolom yang sama menunjukkan berbeda tidak nyata menurut uji Duncan pada taraf $5 \%$

Kompetisi yang terjadi antara tanaman rumput odot dan kacang tanah dalam memperoleh unsur hara dan cahaya matahari, sehingga biji yang terbentuk lebih kecil karena hasil fotosintat yang dihasilkan untuk membentuk biji rendah. Hal ini sesuai dengan Rosmaiti et al. (2017) bahwa penyerapan unsur hara tanaman yang tercukupi dan froses fotosintesis yang berlangsung secara optimal menghasilkan banyak cadangan makanan yang dapat digunakan untuk mengisi polong kacang tanah.

\section{KESIMPULAN}

Jarak tanam rumput gajah var. odot terbaik terhadap pertumbuhan dan produksi rumput gajah var. odot dan kacang tanah diperoleh dari perlakuan J1 $(90 \mathrm{~cm} \times 60 \mathrm{~cm})$, waktu tanam kacang tanah terbaik terhadap pertumbuhan dan produksi rumput gajah var. odot dan kacang tanah diperoleh pada perlakuan T1. Rumput gajah var. Odot baik dicampur tanam dengan kacang tanah dengan memperhatikan jarak tanam yang lebih lebar dan waktu tanam yang tepat.

\section{UCAPAN TERIMA KASIH}

Kepada Rektor Universitas Diponegoro yang telah membantu sebagian dana penelitian melalui skema PNBP Fakultas Peternakan dan Pertanian UNDIP T.A. 2020.

\section{DAFTAR PUSTAKA}

Amin, A. A., Yulia, A. E., \& Nurbaiti. (2017). Pemanfaatan limbah cair tahu untuk pertumbuhan dan produksi tanaman pakcoy (Brassica rapa L.). J. JOM Faperta, 4(2), 1-11.

Amin, M., \& Zubaidah, S. (2018). Respon pupuk urea dan pupuk kandang terhadap jarak tanam dan produksi rumput gajah odot (Pennisetum purpureum. Cv.mott). J. Ilmiah Peternakan, 6(1), 20-26.

Balitkabi. (2018). Balai Penelitian Tanaman Aneka Kacang dan Umbi. Info Teknologi, Katana 1 dan Katana 2. http://balitkabi.litbang.pertanian.go.id/infotek/katana1-dan-katana-2-kacang-tanah-provitas-tinggi-dan- tahan-penyakit-layu-bakteri/. $\quad$ Diakses tanggal $10 / 4 / 2021$.

BMKG. 2019. Badan Meteorologi Klimatologi dan Geofisika Stasiun Klimatologi Semarang. https://dataonline.bmkg.go.id/aksems_data. Diakses tanggal 10/1/2021.

BPS. 2017. Kabupaten Semarang dalam Angka 2017. Ungaran, Kabupaten Semarang.

BPS. 2019. Kecamatan Ungaran Timur Dalam Angka 2019. Ungaran, Kabupaten Semarang.

Dharmawangsa. L., Nujanah, U., Pujiwati, H., Setyowati, N., \& Prasetyo, P. (2020). Nilai kesetaraan lahan dan hasil jagung manis tumpangsari dengan kacang-kacangan di pertanian organik. Prosiding Seminar Nasional Lahan Suboptimal ke-8 Tahun 2020. ISBN: 978-979-587903-9, $224-236$.

Kesuma, A., Nurmauli, N., Timotiwu, P. B., \& Hamim, H. (2018). Efisiensi pupuk urea dan lahan dalam meningkatkan hasil jagung "double row" pada pola tanam tumpang sari dengan kacang tanah. $J$. Penelitian Pertanian Terapan, 18(3), 153-158.

Lasamadi, R. D., Malalantang, S. S., Rustandi, \& Anis, S. D. (2013). Pertumbuhan dan perkembangan rumput gajah dwarf (Pennisetum purpureum cv. Mott) yang diberi pupuk organik hasil fermentasi em4. Zootek, 32(5), 158-171.

Lestari, A. T., Aksarah, A., \& Noer, H. (2020). Pengaruh waktu tanam terhadap pertumbuhan dan hasil tanaman jagung manis yang ditumpangsarikan dengan tanaman kacang tanah. Agrotech, 1(1), 1-8.

Luthfiana, H. A., Haryono, G., \& Historiawati. (2019). Hasil tanaman kubis bunga (Brassica oleracea var. botrytis L.) pada jarak tanam dan mulsa organik. J. Vigor, 4(1), 18-23.

Manyamsari, I., \& Mujiburrahmat. (2014). Karakteristik petani dan hubungannya dengan kompetensi petani lahan sempit. J. Agrisep, 15(2), 58-74.

Permanasari, I., \& Kastono, D. (2012). Pertumbuhan tumpangsari jagung dan kedelai pada perbedaan waktu tanam dan pemangkasan jagung. $J$. Agroteknologi. 3(1), 13-21. 
Rosmaiti, Iswahyudi, \& Azhari. (2017). Pertumbuhan dan hasil kacang tanah (Arachis hypogeae, L) pada berbagai ukuran benih dan kedalaman olah tanah. $J$. Agrosamudra, 4(2), 46-58.

Sadmaka, Suwardji, \& Hemon, A. F. (2017). Pertumbuhan dan hasil kacang tanah yang diberi rhizobium pada cekaman kekeringan. J. Agroteksos, 26(2), 1-10.

Saputro, A.L., Hamid, I. S., Prastiya, R. A., \& Purnama, M. T. E. (2018). Hidroponik fodder jagung sebagai substitusi hijauan pakan ternak ditinjau dari produktivitas susu kambing sapera. J. Medik Veteriner, 1(2), 48-52.

Sari, R., \& Prayudyaningsih. (2017). Peran extracellular polysaccharides (eps) dalam simbiosis legumrhizobia. J. Info Teknis EBONI, 14(2), 77-88.
Sirenden, R. T., Anwar, M., \& Damanik, Z. (2016). Pertumbuhan dan hasil tanaman kedelai (Glycine max Merr) yang diberi pupuk nitrogen dan molibdenum pada tanah podsolik merah kuning. J. Agrium, 13(2), 69-74.

Sulaiman, W. A., Dwatmaji, \& Suteky, T. (2018). Pengaruh pemberian pupuk feses sapi dengan dosis yang berbeda terhadap pertumbuhan dan produksi rumput odot (Pennisetum purpureum cv. Mott) di Kabupaten Kepahiang. J. Sain Peternakan Indonesia, 13(4), 365376.

Suryantini. (2015). Monograf balitkabi no. 13: pembintilan dan penambatan nitrogen pada tanaman kacang tanah. Balai Penelitian Tanaman Aneka Kacang dan Umbi. ISBN 978-602-95497-7-5. 